\title{
MODEL PENGENDALIAN INTERNAL BERBASIS SARBANES-OXLEY ACT DAN KEANDALAN PELAPORAN KEUANGAN (STUDI INTERNAL AUDIT PADA PERUSAHAAN PUBLIK DI INDONESIA)
}

\author{
Syahril Djaddang \\ Fakultas Ekonomi dan Bisnis, Universitas Pancasila \\ syahrildjaddang@rocketmail.com \\ Shanti Lysandra \\ Fakultas Ekonomi dan Bisnis, Universitas Pancasila
}

\begin{abstract}
This study focus on internal control application based on the Sarbanes-Oxley Act. The research objective is to examine the impact of Sarbanes-Oxley Act implementation and the financial reporting reliability toward audit quality and audit opinion. The research is conducted on public companies implementing SarbanesOxley Act in Indonesia. The internal audit section in the companies are used as respondents. Based on questionnaires distributed, there were 35 samples of public companies used in this research. This study employs WarpPLS to handle the SEM model in testing the hypotheses and multigroup analysis to conduct the sensitivity analysis. The research's results showed that application of Sarbanes-Oxley Act based internal control and financial reporting reliability are positively affect the audit opinions and directly influence the audit quality. However, the independent auditor's opinion is not a moderating variables between other variables. The research results are expected to be used as considerations by the companies in implementation of Sarbanes-Oxley Act based internal control.
\end{abstract}

Keywords: audit quality, audit opinion, Sarbanes-Oxley Act, financial reporting reliability, internal control

\section{PENDAHULUAN}

Pengendalian internal memiliki arti penting dalam rangka mencegah terjadinya praktik kecurangan (fraud). Fraud dapat terjadi kapan saja diperusahaan mana saja. Fraud dapat dilakukan oleh pihak internal perusahaan (karyawan dan manajemen) atau pihak eksternal perusahaan. Fraud biasanya terjadi karena adanya kolusi, baik yang dilakukan oleh pihak internal maupun pihak eksternal perusahaan. Bagi perusahaan publik, fraud yang sangat merugikan pihak investor, pemegang saham serta pemangku kepentingan lainnya adalah kecurangan pelaporan keuangan (fraudulent financial reporting). 
Skandal jatuhnya perusahaan besar seperti Enron dan WorldCom di bursa saham Amerika Serikat tahun 2002, disebabkan karena salah urus dan manipulasi (fraud) laporan keuangan yang mengakibatkan rusaknya kepercayaan publik dan investor. Sebagai upaya mengembalikan kepercayaan pasar, maka dikeluarkanlah regulasi Sarbanes-Oxley Act (2002) oleh US Securities and Exchange Commission (SEC) yang memuat ketentuan baru untuk memperkuat governance dan struktur akuntabilitas perusahaan publik.

Sarbanes-Oxley Act (SOA) merupakan sebuah produk hukum di Amerika Serikat yang mengatur tentang akuntabilitas, praktik akuntansi dan keterbukaan informasi, termasuk tata cara pengelolaan data di perusahaan publik. Eksistensi Sarbanes-Oxley Act tersebut diprakarsai oleh senator Paul Sarbanes dari Maryland dan Michael Oxley wakil rakyat dari Ohio dan telah disahkan oleh presiden AS George W. Bush.

Beberapa literatur mengakui pentingnya studi hubungan antara kualitas audit dengan peran pengendalian internal berbasis Sarbanes-Oxley Act dan keandalan pelaporan keuangan. Lennox (1999), menyatakan bahwa kantor akuntan publik yang besar akan lebih mampu menangkap sinyal adanya penyelewengan keuangan dan mengungkapnya dalam opini audit. Hasil penelitian tersebut menjelaskan adanya hubungan yang positif antara penerapan pengendalian internal berbasis SarbanesOxley Act dengan kualitas audit. Di Indonesia, hubungan antara kualitas audit dengan ukuran kantor akuntan serta opini audit belum dapat dilihat dengan jelas. Pada sektor publik, audit biasanya dilakukan oleh BPKP. Audit akan dilakukan oleh kantor akuntan publik, jika pemeriksaan tersebut diminta oleh BPKP.

Penelitian Sugirachmawati dan Djaddang (2013) menyatakan bahwa Penerapan Sarbanes-Oxley Act di Indonesia dan keandalan pelaporan keuangan berpengaruh positif terhadap opini auditor independen, serta berpengaruh tidak langsung dengan kualitas audit. Jika penerapan Sarbanes-Oxley Act dan keandalan pelaporan keuangan sudah baik, maka hal tersebut dapat menghasilkan opini audit wajar tanpa pengecualian. Mansouri et al. (2009) menyatakan bahwa independensi audit mempunyai hubungan positif dengan kualitas audit. Namun pengendalian internal berbasis Sarbanes-Oxley Act tidak terbukti mempunyai hubungan signifikan terhadap kualitas audit.

Murdijaningsih (2014) menyatakan bahwa untuk mengatasi kecurangan laporan keuangan, perusahaan melakukan tata kelola keuangan yang baik berbasis Sarbanes-Oxley Act melalui keputusan direksi mengenai anti fraud. Untuk membuat tata kelola keuangan yang baik berdasarkan Sarbanes-Oxley Act, perusahaan menerapkan seksi 404 yang mensyaratkan bahwa manajemen perusahaan bertanggung jawab atas pengendalian internal terhadap pelaporan keuangan yang memadai, agar dapat memberikan jaminan yang cukup terkait dengan keandalan pelaporan keuangan. Beneish et al. (2007) meneliti tiga ratus delapan puluh tiga 
perusahaan yang membuat pengungkapan audit berdasarkan seksi 404 dari SarbanesOxley Act dan tidak menemukan adanya bukti pengaruh terhadap opini audit dan kualitas audit.

Lai (2003) membuktikan bahwa setelah penerapan Sarbanes-Oxley Act, auditor lebih cenderung mengeluarkan opini audit yang dimodifikasi. Dengan menggunakan isu opini audit modifikasi sebagai ukuran independensi auditor, hasil penelitian tersebut menemukan adanya hubungan positif antara peran pengendalian internal Sarbanes-Oxley Act dengan opini audit dan hubungan negatif terhadap kualitas audit.

Kualitas audit ditentukan oleh dua hal yaitu kompetensi dan independensi, sesuai yang dinyatakan dalam Financial Accounting Standard Committee (AAA 2000). Seorang auditor harus dapat bersikap independen saat melaksanakan tugasnya, terutama saat ia menghadapi konflik dengan klien. Ketika auditor tidak mendapatkan kata sepakat dengan klien, auditor cenderung untuk melakukan apa yang diminta oleh klien karena auditor tidak ingin kehilangan kliennya. Selain itu ketika terdapat ikatan ekonomi yang kuat antara auditor dengan sebuah kantor akuntan publik, auditor memiliki insentif untuk mengabaikan potensi masalah dan mengeluarkan pendapat wajar pada laporan keuangan auditee. Hasil-hasil penelitian yang tidak konsisten di atas menjadi pijakan penulis untuk penelitian kali ini.

Hasil penelitian ini dapat memberikan kontribusi berupa model penerapan pengendalian internal berbasis Sarbanes-Oxley Act bagi regulator dan perusahaan publik di Indonesia. Diharapkan perusahaan publik akan memiliki sistem yang lebih baik, sehingga akuntabilitas dan integritas pelaporan keuangannya dapat lebih dipercaya dan diandalkan. Selanjutnya, adanya keterandalan tersebut akan menjadi daya tarik bagi investor untuk menanamkan modalnya di perusahaan yang bersangkutan karena informasi keuangan yang diterbitkan oleh perusahaan akan lebih dipercaya. Pada gilirannya keterandalan tersebut akan membawa manfaat berupa citra yang positif di mata publik dan pemangku kepentingan lainnya.

Perusahaan publik yang pernah mengalami keterpurukan dalam pelaporan keuangan kini berusaha menerapkan pengendalian internal berbasis Sarbanes-Oxley Act dan untuk menciptakan keandalan laporan keuangan. Hal tersebut berkaitan dengan opini auditor dan kualitas audit yang bersumber dari laporan keuangan yang andal. Keandalan laporan keuangan juga merupakan kontribusi dari adanya standar audit yang antara lain tercermin dari Sarbanes-Oxley Act. Pendapat auditor atas laporan keuangan diungkapkan melalui opini audit. Opini wajar tanpa pengecualian dari auditor menjamin angka-angka akuntansi dalam laporan keuangan yang telah diaudit bebas dari salah saji material dan penerapan pengendalian internal berbasis Sarbanes-Oxley Act. Auditor akan mengalami dilema saat ia menghadapi konflik dengan klien, dimana ia dituntut untuk bersikap independen sekaligus tidak ingin kehilangan kliennya. Kemampuan auditor untuk mempertahankan independensinya 
diduga akan sangat bergantung pada etika profesional yang ia miliki. Penerapan pengendalian internal berbasis Sarbanes-Oxley Act dan keandalan laporan keuangan tidak lepas dari peran auditor independen.

Auditor independen mempunyai peran penting dalam menjembatani kepentingan investor dan kepentingan perusahaan sebagai pemakai dan penyedia laporan keuangan. Kinerja perusahaan akan lebih mudah dipercaya oleh investor dan pemakai laporan keuangan lainnya, apabila laporan keuangan yang mencerminkan kinerja dan kondisi keuangan perusahaan telah mendapat pernyataan wajar dari auditor. Berdasarkan uraian dalam latar belakang di atas, maka permasalahan penelitian dapat dirumuskan sebagai berikut.

1. Apakah penerapan pengendalian internal berbasis Sarbanes-Oxley Act dan keandalan pelaporan keuangan berpengaruh terhadap opini audit?

2. Apakah penerapan pengendalian internal berbasis Sarbanes-Oxley Act dan keandalan pelaporan keuangan berpengaruh terhadap kualitas audit?

3. Apakah penerapan pengendalian internal berbasis Sarbanes-Oxley Act dan keandalan pelaporan keuangan berpengaruh terhadap kualitas audit yang dimediasi oleh opini audit?

\section{TELAAH PUSTAKA DAN PENGEMBANGAN HIPOTESIS}

\section{Teori Stakeholder}

Perkembangan bisnis di era modern menuntut perusahaan untuk lebih memperhatikan seluruh pemangku kepentingan yang ada dan tidak terbatas hanya kepada pemegang saham. Hal ini selain merupakan tuntutan etis, juga diharapkan akan mendatangkan manfaat ekonomi dan menjaga keberlangsungan bisnis perusahaan. Dari perspektif hubungan antara perusahaan dengan seluruh pemangku kepentingan inilah, teori stakeholder kemudian dikembangkan.

Istilah stakeholder pertama kali diperkenalkan oleh Standford Research Institute (RSI) ditahun 1963. Hingga Freeman mengembangkan eksposisi teoritis mengenai stakeholder ditahun 1984 dalam karyanya yang berjudul Strategic Management: A Stakeholder Approach. Freeman (2010) mendefinisikan bahwa stakeholder merupakan kelompok maupun individu yang dapat memengaruhi atau dipengaruhi oleh proses pencapaian tujuan suatu organisasi.

Asumsi teori stakeholder dibangun atas dasar pernyataan bahwa perusahaan berkembang menjadi sangat besar dan menyebabkan masyarakat menjadi sangat terkait dan memperhatikan perusahaan, sehingga perusahaan perlu menunjukkan akuntabilitas maupun responsibilitas secara lebih luas dan tidak terbatas hanya kepada pemegang saham. Hal ini berarti, perusahaan dan stakeholder membentuk hubungan yang saling memengaruhi. Terdapat tiga argumen yang mendukung 
pengelolaan perusahaan berdasarkan perspektif teori stakeholder, yakni argumen deskriptif, argumen instrumental dan argumen normatif.

Argumen deskriptif menyatakan bahwa pandangan pemangku kepentingan secara sederhana merupakan deskripsi yang realistis mengenai bagaimana perusahaan sebenarnya beroperasi atau bekerja. Manajer harus memberikan perhatian penuh pada kinerja keuangan perusahaan, akan tetapi tugas manajemen lebih penting dari itu. Untuk dapat memperoleh hasil yang konsisten, manajer harus memberikan perhatian pada produksi produk-produk berkualitas tinggi dan inovatif bagi para pelanggan mereka, menarik dan mempertahankan karyawan-karyawan yang berkualitas tinggi serta mentaati semua regulasi pemerintah yang cukup kompleks. Secara praktis, manajer mengarahkan energi mereka terhadap seluruh pemangku kepentingan, tidak hanya terhadap pemilik saja.

Argumen instrumental menyatakan bahwa sikap manajemen terhadap pemangku kepentingan dinilai sebagai suatu strategi perusahaan. Perusahaanperusahaan yang mempertimbangkan hak dan memberi perhatian pada berbagai kelompok pemangku kepentingan akan menghasilkan kinerja yang lebih baik.

Argumen normatif menyatakan bahwa sikap manajemen terhadap pemangku kepentingan merupakan hal yang benar untuk dilakukan. Perusahaan mempunyai penguasaan dan kendali yang cukup besar terhadap banyak sumber daya. Hak istimewa ini menyebabkan adanya kewajiban perusahaan terhadap semua pihak yang mendapat efek dari tindakan-tindakan perusahaan.

\section{Pengendalian Internal dan Sarbanes-Oxley Act}

Sarbaness-Oxley Act diterbitkan untuk memproteksi kepentingan investor dengan cara menciptakan tata kelola perusahaan yang baik (good corporate governance), full disclosure dan akuntabilitas dalam perusahaan. Untuk mewujudkan hal tersebut, Sarbanes-Oxley Act mengatur mengenai pengendalian internal perusahaan secara lebih intensif. Konsep pengendalian internal dalam SarbanesOxley Act terdapat pada seksi 302 dan 404.

Sarbanes-Oxley Act merupakan sebuah undang-undang yang dirancang setelah terjadinya skandal korporasi besar di Amerika Serikat, yang melibatkan perusahaan besar seperti: Enron, Tyco International, Adelphia, Peregrine Systems, WorldCom (MCI), AOL TimeWarner, Aura Systems, Citigroup, Computer Associates International, CMS Energy, Global Crossing, HealthSouth, Quest Communication, Safety-Kleen dan Xerox, yang juga melibatkan beberapa KAP yang termasuk dalam "the big five" seperti: Arthur Andersen, KPMG dan PWC. Skandal tersebut menyebabkan kerugian miliaran dolar bagi investor karena runtuhnya harga saham perusahaan-perusahaan yang terpengaruh ini mengguncang kepercayaan masyarakat terhadap pasar saham. Semua skandal ini merupakan contoh tragis bagaimana kecurangan (fraud schemes) berdampak sangat buruk terhadap pasar, stakeholder dan para pegawai. Dengan diberlakukannya undang-undang 
Sarbanes-Oxley Act, diharapkan dapat membawa dampak positif bagi berbagai profesi, antara lain: akuntan publik bersertifikat (CPA), kantor akuntan publik (KAP), perusahaan yang memperdagangkan sahamnya listed di bursa (termasuk direksi, komisaris, karyawan, dan pemegang saham), perantara (broker), penyalur (dealer), pengacara yang berpraktik untuk perusahaan publik, investor perbankan serta para analis keuangan.

\section{Kualitas Audit}

Pada dasarnya, audit digunakan untuk menjamin keandalan laporan keuangan. Audit perlu dilakukan untuk memantau kebijakan atas pelaporan manajerial, sehingga dapat mengurangi risiko informasi. Lebih tepatnya, peran audit adalah untuk mengurangi asimetri informasi pada angka akuntansi dan untuk meminimalkan kerugian yang dihasilkan dari sifat oportunisme manajer keuangan dalam pelaporan (Adeyemi dan Fagbemi 2010). Seorang auditor dituntut untuk menghasilkan opini audit yang berkualitas karena laporan keuangan tersebut akan menjadi acuan dari berbagai pihak dalam mengambil keputusan. Ikatan Akuntan Indonesia (IAI) menyatakan bahwa audit yang dilakukan auditor dikatakan berkualitas jika memenuhi standar audit dan standar pengendalian mutu. Kualitas audit ditentukan oleh dua hal yaitu kompetensi dan independensi (AAA 2000).

Pengendalian internal merupakan metoda yang berguna bagi manajemen untuk menjaga kekayaan organisasi, meningkatkan efektivitas dan efisiensi kinerja. Disamping itu, sistem pengendalian intern dapat mengendalikan ketelitian dan akurasi pencatatan data akuntansi. Menurut Arens et al. (2008), tujuan umum pengendalian internal adalah mencapai effectiveness and efficiency of operations, reliability of financial reporting serta complience with external laws and regulations.

\section{Penerapan Pengendalian Internal berbasis Sarbanes-Oxley Act terhadap Opini Auditor}

Petunjuk Pelaksanaan Pemeriksaan Keuangan (Keputusan Badan Pemeriksan Keuangan Republik Indonesia Nomor 04/K/I-XII.2/5/2008) menyatakan perlunya pemeriksa mengevaluasi apakah sistem pengendalian internal (SPI) telah didesain secara memadai dan dapat meminimalkan salah saji dan kecurangan. Pengujian implementasi SPI dilakukan dengan melihat pelaksanaan pengendalian pada kegiatan atau transaksi yang dilakukan oleh pihak yang terperiksa.

Pengujian SPI merupakan dasar pengujian substantif selanjutnya yang akan dilakukan oleh auditor. Selain berfungsi sebagai salah satu kriteria dalam penetapan opini, hasil pengujian atas SPI diungkapkan dalam hal jika dan hanya jika ditemukan kelemahan-kelemahan pengendalian internal selama pelaksanaan pemeriksaan. Laporan efektivitas pengendalian internal disyaratkan Sarbanes-Oxley Act khususnya seksi 302 mengenai sertifikasi atas pelaporan keuangan. Dapat dipersepsikan bahwa efektivitas pengendalian internal berbasis Sarbanes-Oxley Act seksi 302 berpengaruh positif terhadap opini auditor independen. 
Konrath (2002) serta Boyton dan Raymond (2006) menjelaskan bahwa penilaian atas sistem pengendalian intern merupakan salah satu penentu jenis opini yang akan diberikan. Konrath (2002) menyatakan bahwa berdasarkan standar pekerjaan lapangan audit kedua, mengharuskan auditor memperoleh pemahaman yang memadai atas SPI klien guna merencanakan audit dan menentukan sifat, waktu dan luas pengujian yang akan dilakukan dan sebagai dasar opini audit. Sugirahmawati dan Djaddang (2013) menyatakan bahwa penerapan Sarbanes-Oxley Act berpengaruh signifikan dan positif terhadap opini auditor, dimana jika penerapan Sarbanes-Oxley Act dilaksanakan dengan baik maka akan dapat menghasilkan opini audit yang baik pula (wajar tanpa pengecualian). Tujuannya adalah auditor mampu mengevaluasi kemungkinan adanya salah saji material pada laporan keuangan klien. Dari uraian di atas, maka hipotesis pertama untuk penelitian ini adalah sebagai berikut.

H1: Terdapat pengaruh positif penerapan pengendalian internal berbasis Sarbanes-Oxley Act terhadap opini audit.

\section{Keandalan Pelaporan Keuangan terhadap Opini Auditor}

Arens et al. (2008) menyatakan bahwa berdasarkan adanya salah saji material, auditor menyatakan pendapat atau opini atas pelaporan keuangan. Hal ini dapat dilihat dari paragraf ruang lingkup dan paragraf pendapat dalam laporan audit bentuk baku. Boynton dan Kell (2002) menyatakan bahwa tujuan utama audit atas laporan keuangan bukan untuk menciptakan informasi baru, melainkan untuk menambah keandalan laporan keuangan yang telah disusun oleh manajemen. Hasil penelitian Sugirahmawati dan Djaddang (2013) menyatakan bahwa keandalan pelaporan keuangan berpengaruh signifikan dan positif terhadap opini auditor. Jika keandalan pelaporan keuangan sudah baik, maka hal tersebut dapat menghasilkan opini audit yang baik pula (wajar tanpa pengecualian).

Auditor memberikan opini atas pelaporan keuangan berdasarkan ada tidaknya salah saji material dan kesesuaian dengan standar akuntansi yang berlaku umum. Informasi yang bebas dari salah saji ini merupakan salah satu definisi dari informasi yang andal. Dari uraian di atas, auditor harus mengeluarkan pendapat mengenai reliabilitas pelaporan keuangan yang diukur dari laporan keuangan yang andal (wajar dan bebas dari salah saji material) dan laporan efektivitas pengendalian internal. Efektivitas pengendalian intern berbasis Sarbanes-Oxley Act dan keandalan pelaporan keuangan berpengaruh terhadap opini auditor independen. Dari uraian di atas, maka hipotesis kedua untuk penelitian ini sebagai berikut.

H2: Terdapat pengaruh positif keandalan pelaporan keuangan terhadap opini audit. 


\section{Penerapan Pengendalian Internal Berbasis Sarbanes-Oxley Act terhadap Kualitas Audit}

Tujuan penerapan Sarbanes-Oxley Act adalah untuk memastikan agar eksekutif bertanggung jawab atas tindakannya. Hal ini memaksa banyak perusahaan untuk membenahi manajemen puncak, menggantikan anggota dewan yang pensiun serta memikirkan kembali perencanaan manajerial dan proses pelaporan keuangan. Tujuan lain dari Sarbanes-Oxley Act adalah memberikan hukuman keras bagi yang melanggar dan memaksa perusahaan patuh di bawah ancaman pidana. SarbanesOxley Act juga dimaksudkan untuk memulihkan kepercayaan investor, meningkatkan kinerja bisnis dan memastikan keandalan laporan keuangan yang diberikan oleh perusahaan publik.

DeAngelo (1981) mendefinisikan kualitas audit sebagai probabilitas dimana seorang auditor menemukan dan melaporkan tentang adanya suatu pelanggaran dalam penerapan pengendalian internal klien. Probabilitas penemuan suatu pelanggaran tergantung pada kemampuan teknikal auditor dan independensi auditor tersebut. Beberapa penelitian seperti DeAngelo (1981), Goldman dan Barlev (1974) serta Nichols dan Price (1976) umumnya mengasumsikan bahwa auditor dengan kemampuannya akan dapat menemukan suatu pelanggaran, namun auditor tersebut harus independen dalam proses audit dan memberikan opini audit. Ukuran kantor akuntan publik dalam Deis dan Giroux (1992) diukur dari jumlah klien dan persentase dari audit fee dalam usaha mempertahankan kliennya untuk tidak berpindah pada kantor akuntan publik yang lain. Penerapan pengendalian internal berbasis Sarbanes-Oxley Act, khususnya akan diberikan kepada hal yang diyakini memiliki dampak langsung pada kegiatan off balance sheet dan meningkatkan kualitas audit. Dari uraian di atas, maka hipotesis ketiga untuk penelitian ini adalah sebagai berikut.

H3a: Terdapat pengaruh positif penerapan pengendalian internal berbasis Sarbanes-Oxley Act terhadap kualitas audit.

H3b: Terdapat pengaruh penerapan pengendalian internal berbasis SarbanesOxley Act terhadap kualitas audit yang dimediasi oleh opini audit.

\section{Keandalan Laporan Keuangan terhadap Kualitas Audit}

Menurut Krishnamoorthy (2002), audit internal seringkali memiliki persamaan tujuan dengan audit eksternal. Hubungan antara keduanya menjadi sorotan utama sebgai persyaratan corporate governance dewasa ini. Lingkungan bisnis sekarang ini membutuhkan peran audit internal dan eksternal yang lebih terkait dan menghasilkan hubungan yang lebih mendalam antara keduanya. Pada kenyataannya, standar audit internal dan eksternal dikordinasikan. Kerjasama antara auditor eksternal dan internal mendorong dua kelompok audit tersebut untuk saling bekerja sama dalam menyelesaikan audit laporan keuangan (AICPA 1997). Menurut Felix et al. (1998 dan 2001) dan Krishnamoorthy (2001), tingkat koordinasi dan 
kerjasama yang tinggi antara audit eksternal dan internal akan meningkatkan keandalan pelaporan keuangan. Interaksi antara keduanya sangat penting untuk tata kelola perusahaan yang efektif dan untuk mencapai pelaporan keuangan dan audit yang berkualitas. Tanpa kemampuan teknis yang baik, maka auditee akan sulit mendapatkan kualitas audit yang memadai dan penyajian laporan keuangan yang andal yang sesuai standar akuntansi yang berlaku sebagai dasar untuk mendapatkan opini audit wajar tanpa pengecualiaan. Dari uraian di atas, maka hipotesis keempat untuk penelitian ini adalah sebagai berikut.

H4a: Terdapat pengaruh positif keandalan pelaporan keuangan terhadap kualitas audit.

H4b: Terdapat pengaruh keandalan pelaporan keuangan terhadap kualitas audit dimediasi oleh opini audit.

\section{Pengaruh Opini Audit terhadap Kualitas Audit}

Laporan audit menggambarkan kondisi perusahaan selama periode yang bersangkutan. Laporan audit juga bertujuan untuk menjaga citra perusahaan di mata publik. Opini auditor yang menyatakan wajar tanpa pengecualian akan mengangkat citra perusahaan di mata publik. Semakin baik citra perusahaan di mata masyarakat yang tercermin dalam opini audit wajar tanpa pengecualiaan, maka akan menjadi daya tarik investor untuk berinvestasi. Dalam memberikan jasanya, kantor akuntan publik berusaha sebaik mungkin untuk mendapatkan kepercayaan dari perusahaan publik dan pihak pengguna laporan keuangan. Perusahaan publik yang dapat memberikan pelayanan terbaik akan menghasilkan laporan keuangan audit yang berkualitas dan opini audit tanpa pengecualiaan sebagai dasar kualitas audit yang memadai.

Lennox (1999), menyatakan bahwa kantor akuntan publik yang besar lebih mampu menangkap sinyal akan penyelewengan keuangan yang terjadi dan mengungkapkannya dalam opini audit. Hasil penelitian tersebut menjelaskan bahwa adanya hubungan yang positif antara penerapan pengendalian internal berbasis Sarbanes-Oxley Act dan kualitas audit. Laporan keuangan suatu perusahaan yang berkualitas akan menjadi daya tarik bagi investor untuk menanamkan modalnya di perusahaan, karena informasi keuangan yang diterbitkan oleh perusahaan lebih dipercaya. Hal tersebut tercermin dalam opini audit dan kualitas audit laporan keuangan. Maka hipotesis dalam penelitian ini sebagai berikut.

H5: Terdapat pengaruh positif opini audit terhadap kualitas audit.

\section{METODA PENELITIAN}

Berdasarkan karakteristik masalah yang akan di teliti, penelitian ini merupakan penelitian kausal. Penelitian kausal merupakan penelitian untuk mengetahui pengaruh antara satu atau lebih variabel bebas (independent variable) 
terhadap variabel terikat (dependent variable). Penelitian kausal ini mengkaji secara empiris mengenai pengaruh penerapan Sarbanes-Oxley Act dan keandalan pelaporan keuangan terhadap opini audit dan kualitas audit. Variabel Independen penelitian ini adalah penerapan Sarbanes-Oxley Act dan keandalan pelaporan keuangan. Sedangkan yang menjadi variabel dependen adalah kualitas audit dan opini audit sebagai variabel mediasi.

Untuk mengukur variabel-variabel dalam penelitian ini, maka akan diturunkan ke dalam masing-masing indikator yang merupakan ciri-ciri dari variabel tersebut. Skala pengukuran masing-masing variabel berbentuk skala ordinal. Operasionalisasi variabel dalam penelitian ini mengacu pada Sarbanes-Oxley Act dalam Arens et al. (2008) yang disajikan lengkap pada lampiran.

\section{Populasi dan Sampel}

Populasi penelitian ini adalah seluruh divisi audit internal perusahaan yang berhubungan dengan penerapan Sarbanes-Oxley Act, yang berjumlah lima puluh perusahaan publik di Jakarta. Data diambil dengan kuesioner yang diedarkan kepada seluruh bagian audit internal, yang terkait dalam pelaksanaan Sarbanes-Oxley Act yang berjumlah tiga puluh lima perusahaan dan yang tidak menerapkan SarbanesOxley Act berjumlah lima belas perusahaan publik. Teknik pengambilan sampel yang digunakan dalam penelitian ini adalah purposive sampling, yaitu metoda pengambilan sampel dengan pertimbangan tertentu. Hanya elemen populasi yang memenuhi kriteria tertentu dari penelitian yang bisa dijadikan sampel. Kriteria yang penulis ambil dalam penyebaran kuesioner ini adalah audit internal yang berkaitan langsung dengan penerapan Sarbanes-Oxley Act.

\section{Teknik Analisis Data}

Pengolahan data dilakukan dengan tabulasi terhadap kuesioner dengan menjumlahkan bobot jawaban pada masing-masing pertanyaan untuk masing-masing variabel. Analisis data yang dilakukan dengan menggunakan teknik statistik deskriptif dan uji hipotesis. Statistik deskriptif digunakan untuk memberikan gambaran mengenai demografi responden penelitian (jabatan, jenis kelamin, lama pengalaman kerja dan latar belakang pendidikan). Data dapat dilihat dari nilai ratarata (mean), standar deviasi, maksimum dan minimum. Uji hipotesis dalam penelitian ini menggunakan alat analisis structural equation modeling dengan program WarpPLS 4.0.. Alat analisis ini dipilih karena ada beberapa kelebihan yaitu didesain untuk dapat menyelesaikan persoalan seperti jumlah sampel yang kecil, data tidak terdistribusi normal secara multivariat, adanya missing value dan adanya problem multikolonearitas antar variabel eksogen (Ghozali dan Latan 2014).

Penelitian ini digunakan untuk mengetahui hubungan antara variabel independen yaitu Sarbanes-Oxley Act dan keandalan pelaporan keuangan, serta variabel dependen kualitas audit dan variabel mesiasi adalah opini audit. Adapun model penelitian ini dalam persamaan jalur yang dibangun sebagai berikut. 
Persamaan Struktur 1:

$\mathrm{y} 1=\beta 1 \zeta 1+\beta 2 \zeta 2+\mathrm{M} \zeta 3+\zeta 1$

Persamaan Struktur 2:

$\mathrm{y} 2=\beta 0+\beta 1 \zeta 1+\beta 2 \zeta 2+\zeta 2$

Keterangan:

$\mathrm{n} 1=$ kualitas audit

y2 = opini audit

$\zeta 1=$ SPI berbasis Sarbanes-Oxley Act

$\zeta 2=$ keandalan pelaporan keuangan

\section{HASIL DAN PEMBAHASAN}

\section{Statistik Deskriptif}

Analisis statistik deskriptif variabel-variabel penelitian ini ditampilkan untuk mengkaji tanggapan umum responden terhadap variabel-variabel yang diteliti.

Tabel 1

Statistika Deskriptif Penelitian

\begin{tabular}{lcccc}
\hline & Minimum & Maksimum & Rata-rata & Standar Deviasi \\
\hline Penerapan SOA & 2,00 & 5 & 3,8000 & 0.67737 \\
Keandalan pelaporan keuangan & 2,00 & 5 & 3,6571 & 0.76477 \\
Opini auditor & 2,00 & 5 & 3,7714 & 0.77024 \\
Kualitas audit & 0,00 & 1 & 0,5000 & 0.00000 \\
\hline
\end{tabular}

Sumber: Data primer yang diolah (2014)

Berdasarkan Tabel 1 diatas dapat diketahui bahwa variabel penerapan Sarbanes-Oxley Act memiliki nilai rata-rata sebesar 3,8. Hal ini menunjukkan bahwa sebagian besar responden cenderung menjawab cukup efektif, untuk pernyataan yang diajukan berkaitan dengan variabel penerapan Sarbanes-Oxley Act. Nilai maksimum variabel penerapan Sarbanes-Oxley Act adalah 5,00 yang artinya terdapat responden yang menjawab sangat efektif. Nilai minimum variabel penerapan Sarbanes-Oxley Act adalah 2,0 yang artinya terdapat responden yang menjawab kurang efektif untuk pernyataan yang diajukan berkaitan variabel penerapan Sarbanes-Oxley Act.

Variabel keandalan pelaporan keuangan memiliki nilai rata-rata sebesar 3,65. Hal ini menunjukkan bahwa sebagian besar responden cenderung menjawab cukup efektif untuk pernyataan yang diajukan berkaitan dengan variabel keandalan pelaporan keuangan. Nilai maksimum variabel keandalan pelaporan keuangan adalah lima yang artinya terdapat responden yang menjawab sangat efektif. Nilai minimum variabel keandalan pelaporan keuangan adalah 2,0 yang artinya terdapat responden yang menjawab kurang efektif untuk pernyataan yang diajukan berkaitan variabel keandalan pelaporan keuangan. 
Variabel opini auditor memiliki nilai rata-rata sebesar 3,77. Hal ini menunjukkan bahwa sebagian besar responden cenderung menjawab cukup efektif untuk pernyataan yang diajukan berkaitan dengan variabel opini auditor. Nilai maksimum variabel opini auditor adalah 5 yang artinya terdapat responden yang menjawab sangat efektif. Nilai minimum variabel opini auditor adalah 2,0 yang artinya terdapat responden yang menjawab kurang efektif untuk pernyataan yang diajukan berkaitan variabel opini auditor, pengukuran kualitas audit menggambarkan auditor yang independen dan kompeten dengan nilai 1 dan yang tidak independen dan tidak kompeten dengan nilai 0 .

\section{Pengujian Validitas dan Reliabilitas Instrumen}

Kuesioner dikatakan reliabel jika nilai dari Cronbach Alpha di atas 0,60. Hasil koefisien Cronbach Alpha lebih besar dari 0,60 untuk keempat variabel penelitian. Dengan demikian, dapat disimpulkan instrumen penelitian ini reliabel. Berdasarkan hasil uji validitas kuesioner, dapat dihat bahwa 16 pertanyaan pada kuesioner masing-masing variabel eksogen dan endogen. Seluruh pernyataan dinyatakan valid karena $r$ hitung rata-rata adalah sebesar 0.415 yang lebih besar dari r tabel yaitu 0.338 .

Tabel 2

Hasil Uji Reliabilitas

\begin{tabular}{lcc}
\hline \multicolumn{1}{c}{ Variabel } & $\begin{array}{c}\text { Koefisien Cronbach's } \\
\text { Alpha }\end{array}$ & Keterangan \\
\hline Variabel eksogen: & & \\
1. Penerapan SOA & 0,892 & Reliabel \\
2. Keandalan pelaporan keuangan & 0,781 & Reliabel \\
Variabel endogen: & & \\
1. Opini auditor & 0,919 & Reliabel \\
2. Kualitas audit & 0,890 & Reliabel \\
\hline
\end{tabular}

Sumber: Data diolah (2014)

\section{Pengujian Hipotesis}

\section{Pengujian Model SEM dengan WarpPLS}

Analisis uji SEM dengan WarpPLS dalam penelitian ini digunakan untuk mengetahui hubungan antara variabel independen yaitu Sarbanes-Oxley Act, keandalan pelaporan keuangan sebagai variabel exogen dan opini audit dan kualitas audit sebagai variabel endogen. Adapun hasil analisis model SEM dengan Warp_PLS 4.0 berikut: 


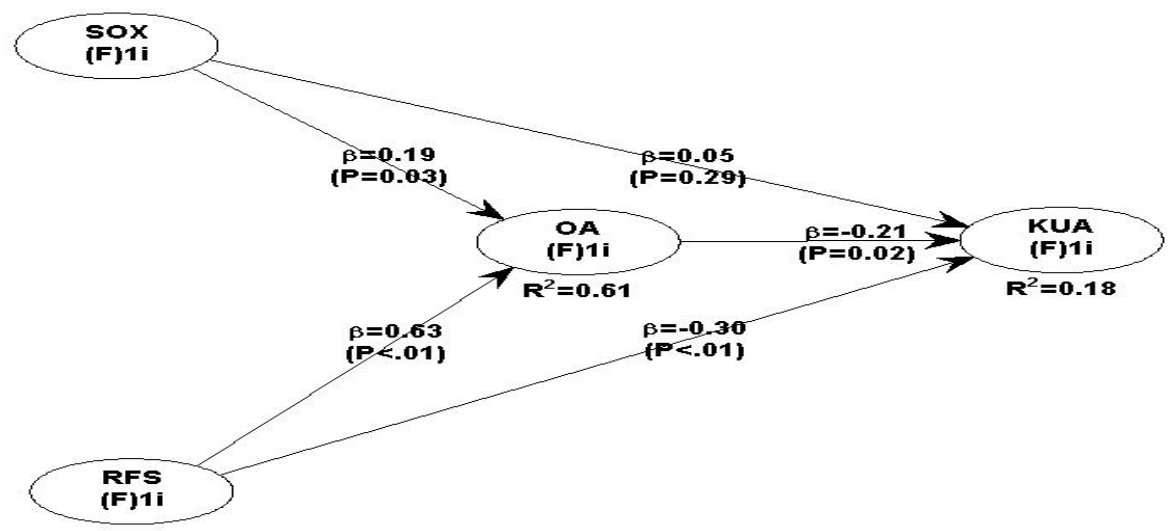

Sumber: Data primer yang diolah (2014)

Gambar 1

Model Single Mediator

\section{HASIL DAN PEMBAHASAN}

Hasil pengujian path coefficient dan $p$ value dipergunakan untuk melihat besarnya koefisien dan tingkat signifikansi hubungan Sarbanes-Oxley Act dan keandalan pelaporan keuangan terhadap kualitas audit, serta opini audit sebagai variabel mediasi adalah sebagai berikut.

Tabel 3

Hasil Path Coefficients dan P Value

\begin{tabular}{lllcc}
\hline & Path & & \multicolumn{2}{c}{ Direct Effect } \\
\cline { 4 - 5 } & & & Koefisien & $\boldsymbol{p}$-Value \\
\hline$S O A$ & $\longrightarrow$ & OA & 0.10 & $0.03^{* *}$ \\
RFS & $\longrightarrow$ & OA & 0.03 & $p<0.01^{* * *}$ \\
$S O A$ & $\longrightarrow$ & KUA & 0.05 & 0.29 \\
RFS & $\longrightarrow$ & KUA & -0.30 & $p<0.01^{* * *}$ \\
OA & $\longrightarrow$ & KUA & -0.21 & $0.02^{* *}$ \\
\hline
\end{tabular}

Sumber: data diolah dalam penelitian ini (2014)

Keterangan:

SOA = Sarbanes-Oxley Act

RFS = Keandalan pelaporan keuangan

$\mathrm{OA}=$ Opini audit

KUA = Kualitas audit

**Signifikan pada level 5\%

***Signifikan pada level 1\%

Hasil olah data untuk pengujian hipotesis satu menunjukkan bahwa SarbanesOxley Act berpengaruh secara signifikan dan positif sebesar 0,10 terhadap opini audit dengan $p$-value sebesar $0,03(p<0,05)$. Oleh karena itu, pengujian terhadap persamaan model pertama menghasilkan kesimpulan yang konsisten dengan 
hipotesis satu (H1 diterima), yaitu penerapan pengendalian internal berbasis Sarbanes-Oxley Act berpengaruh positif dan signifikan terhadap opini audit.

Variabel keandalan pelaporan keuangan berpengaruh secara positif sebesar 0,03 dan signifikan terhadap opini audit, dengan $p$-value sebesar 0,001 $(p<0,05)$. Oleh karena itu, pengujian terhadap persamaan model dua menghasilkan kesimpulan yang konsisten dan signifikan dengan hipotesis dua (H2 diterima), yaitu keandalan pelaporan keuangan berpengaruh positif dan signifikan terhadap opini audit.

Untuk variabel penerapan Sarbanes-Oxley Act, ditemukan pengaruh secara positif sebesar 0,05 terhadap kualitas audit, namun tidak signifikan karena memiliki $p$-value sebesar $0,29(p>0,05)$. Hasil ini tidak mendukung hipotesis penelitian karena penerapan pengendalian internal berbasis Sarbanes-Oxley Act tidak dapat meningkatkan kualitas audit laporan keuangan. Oleh karena itu, pengujian terhadap persamaan model tiga menghasilkan kesimpulan yang tidak konsisten dengan hipotesis tiga (H3 ditolak), yaitu penerapan internal kontrol berbasis Sarbanes-Oxley Act berpengaruh positif terhadap kualitas audit laporan keuangan.

Sedangkan variabel keandalan pelaporan keuangan (RFS) berpengaruh secara negatif sebesar -0,30 dan signifikan terhadap kualitas audit dengan $p$-value sebesar $0,001(p<0,001)$. Oleh karena itu pengujian terhadap persamaan model empat menghasilkan kesimpulan yang konsisten dengan hipotesis empat (H4 diterima), yaitu keandalan pelaporan keuangan berpengaruh negatif terhadap kualitas audit. Keandalan pelaporan keuangan akan menekankan kepada lemahnya kualitas audit atas informasi keuangan, sehingga akan memperbaiki prosedur audit dan tentunya dapat mereduksi kecurangan yang material dan meningkatkan kualitas audit. Pengukuran keandalan pelaporan keuangan yang memadai, terletak pada perilaku akuntan publik dalam melaksanakan audit. Pada kantor akuntan publik kriteria yang ditetapkan sebagai audit yang berkualitas dan memadai adalah kepatuhan dan sikap profesional auditor untuk mengikuti aturan yang telah ditetapkan, beserta program audit yang ditentukan melalui prosedur audit.

Variabel opini audit berpengaruh secara negatif sebesar -0,21 dan signifikan terhadap kualitas audit dengan $p$-value sebesar 0,02 $(p<0,05)$. Oleh karena itu pengujian terhadap persamaan model lima menghasilkan kesimpulan yang tidak konsisten dengan hipotesis lima (H5 ditolak), yaitu opini audit pelaporan keuangan berpengaruh positif dan signifikan terhadap kualitas audit.

\section{Pengujian Model Fit and Quality Indices}

Berdasarkan hasil pengujian model fit and quality indices, dapat diketahui bahwa nilai average block VIF $(A V I F)=2.276$, acceptable if $<=5$, ideally $<=3.3$ serta average full collinearity VIF $(A F V I F)=2.091$, acceptable if $<=5$, ideally $<=3.3$. Hal ini menunjukkan bahwa APC, ARS, SPR, RSCR dan SSR adalah acceptable, maka model penelitian yang dibentuk dapat digunakan untuk memprediksi pengaruh variabel independen terhadap variabel dependen. Dapat diketahui bahwa terdapat 
pengaruh penerapan pengendalian internal berbasis Sarbanes-Oxley Act dan keandalan pelaporan keuangan terhadap kualitas audit melalui opini audit sebesar 0,18 atau $18 \%$ dan sisanya 82\% dipengaruhi oleh variabel diluar model penelitian ini.

\section{Uji Single-Mediator}

Untuk mengetahui besarnya varian dari indirect effect, dapat dihitung dengan menggunakan rumus variance accounted for (VAF). Nilai VAF berkisar antara 0 sampai 1. Semakin tinggi $V A F$ menunjukkan bahwa pengaruh efect mediasi yang sempurna. VAF dapat dihitung dengan menggunakan rumus Ghozali (2014).

$V A F=\frac{a \times b}{a \times b+c} \times 100 \%$

Dari hasil analisis WarpsPLS 4.0 di atas didapat hasil nilai VAF variabel Sarbanes-Oxley Act sebesar 0,047. Jadi besarnya nilai pengaruh indirect effect hubungan penerapan Sarbanes-Oxley Act terhadap kualitas audit tidak dimediasi oleh opini audit karena nilai $V A F$ sebesar 4,74 persen masih berkisar antara 0-1, namun tidak signifikan dengan nilai p-value 0,282 > 0,05. Sedangkan nilai VAF variabel RFS adalah sebesar 0,12. Jadi nilai indirect effect hubungan variabel RFS terhadap KUA dimediasi oleh opini audit adalah sebesar 12\%, yang berarti ada mediasi parsial (partial mediation) pada hubungan antara keandalan pelaporan keuangan terhadap kualitas audit. Mediasi oleh opini audit dengan nilai VAF sebesar 0,12 berkisar antara $0-1$ dan signifikan 0,033 $<0,05$.

Tabel 4

Variance Accounted For (VAF) Indirect Effect

\begin{tabular}{cccc}
\hline & \multicolumn{2}{c}{ Indirect Effect } & \multirow{2}{*}{ VAF } \\
\cline { 2 - 3 } Relationship & Standard Error & P-Value & \\
\cline { 1 - 3 }$S O A \rightarrow \mathrm{OA} \rightarrow \mathrm{KUA}$ & 0.068 & 0.282 & $4,74 \%$ \\
$\mathrm{RFS} \rightarrow \mathrm{OA} \rightarrow \mathrm{KUA}$ & 0.068 & $0.033^{* *}$ & $12 \%$ \\
\hline
\end{tabular}

Sumber: data diolah (2014)

Keterangan:

SOA = Sarbanes-Oxley act

RFS $\quad=$ Keandalan pelaporan keuangan

OA $=$ Opini audit

KUA = Kualitas audit

**Signifikan pada level 5\% 


\section{Nilai $R$-Squared}

Adapun nilai $R$-squared pada penelitian ini sebagai berikut:

Tabel 5

Nilai Koefisien $R$-Squared

\begin{tabular}{lc}
\hline \multicolumn{1}{c}{ Variabel Dependen } & R-Squared \\
\hline Opini audit & 0.61 \\
Kualitas audit & 0.18 \\
\hline
\end{tabular}

Sumber: Data diolah (2014)

Hasil pengujian statistik menunjukkan nilai $R$-squared sebesar 0.61, yang memiliki arti bahwa pengaruh variabel penerapan pengendalian internal berbasis Sarbanes-Oxley Act dan keandalan pelaporan keuangan terhadap opini audit adalah sebesar 61 persen dan sisanya 39 persen dipengaruhi oleh variabel diluar model penelitian ini. Penerapan pengendalian internal berbasis Sarbanes-Oxley Act dan keandalan pelaporan keuangan terhadap kualitas audit melalui opini audit adalah sebesar 0,18 atau 18 persen dan sisanya 82 persen dipengaruhi oleh variabel diluar model penelitian ini.

\section{Uji Sensitivitas Multi Group}

Untuk mengkonfirmasi nilai koefisien $R$-squared dilakukan uji sensitivitas dengan multi group pada hubungan antara variabel penerapan Sarbanes-Oxley Act dan keandalan pelaporan keuangan terhadap variabel opini audit. Koefisien determinasi variabel Sarbanes-Oxley Act sebesar 0,127 dan keandalan pelaporan keuangan adalah sebesar 0,483. Koefisien determinasi variabel mediasi opini audit adalah 0,61 yang berarti masih konsisten sebesar 61 persen. Sedangkan variabel SOA sebesar -0,016, keandalan pelaporan keuangan sebesar 0,119 dan mediasi opini audit terhadap kualitas audit sebesar 0,078, sehingga besarnya total koefisien determinasi adalah 0,18. Hal ini berarti koefisien determinasi adalah masih konsisten dengan koefisien $R$-squared.

\section{Pembahasan Hasil Penelitian}

Pembahasan pengujian hipotesis penelitian dapat dirangkum pada tabel di bawah ini. Hasil penelitian digambarkan sesuai dengan model penelitian empiris sebagai berikut. 
Tabel 6

Rangkuman Hasil Pengujian Hipotesis

\begin{tabular}{|c|c|c|c|c|c|c|}
\hline \multicolumn{3}{|c|}{ Hubungan } & Hipotesis & P-Value & VAF & Pengujian Hipotesis \\
\hline$S O A$ & $\rightarrow$ & $\mathrm{OA}$ & H1 & $0,030^{* *}$ & - & Didukung \\
\hline RFS & $\rightarrow$ & OA & $\mathrm{H} 2$ & $<0,00^{* * *}$ & - & Didukung \\
\hline$S O A$ & $\rightarrow$ & KUA & НЗа & 0,29 & - & Tidak didukung \\
\hline$S O A$ & OA & KUA & H3b & 0,282 & 0,047 & No Mediation \\
\hline$R F S$ & $\rightarrow$ & KUA & $\mathrm{H} 4 \mathrm{a}$ & $0,033^{* *}$ & - & Didukung \\
\hline RFS & $\mathrm{OA}$ & KUA & $\mathrm{H} 4 \mathrm{~b}$ & $0,033^{* *}$ & 0,12 & Partial Mediation \\
\hline $\mathrm{OA}$ & $\rightarrow$ & KUA & H5 & $0,02 * *$ & - & Tidak didukung \\
\hline
\end{tabular}

Sumber: Data primer yang diolah (2014)

Keterangan:

**Signifikan pada $5 \%$

*** Signifikan pada $1 \%$

Berdasarkan hasil pengujian statistik, dapat dilihat bahwa variabel independen yaitu penerapan Sarbanes-Oxley Act dan keandalan pelaporan keuangan berpengaruh signifikan terhadap opini audit. Dengan nilai koefisien determinasi sebesar 0,61, berarti 61 persen perubahan opini audit dipengaruhi oleh penerapan Sarbanes-Oxley Act dan keandalan pelaporan keuangan. Sedangkan sisanya (39 persen) dijelaskan oleh faktor lain diluar model. Pengaruh keandalan pelaporan keuangan terhadap kualitas audit melalui opini audit sebesar 18 persen dan sisanya 82 persen dipengaruhi oleh faktor lain diluar model penelitian ini.

Dari hasil pengujian dapat dilihat bahwa penerapan Sarbanes-Oxley Act berpengaruh signifikan dan positif terhadap opini audit, sebagaimana telah disajikan pada uji hipotesis di atas dengan signifikansi pada $0,03(<0,05)$. Dari hasil pengujian tersebut dapat disimpulkan bahwa penerapan pengendalian internal berbasis Sarbanes-Oxley Act secara langsung tidak signifikan memengaruhi kualitas audit dan tidak dimediasi oleh opini audit. Hal ini dimungkinkan karena auditor menganggap penerapan pengendalian internal berbasis Sarbanes-Oxley Act bukan salah satu faktor yang mereka pertimbangkan dalam meningkatkan kualitas audit laporan keuangan. Hal ini mengindikasikan bahwa penerapan pengendalian internal berbasis Sarbanes-Oxley Act dapat memperlemah hubungan secara lansung terhadap kualitas audit, karena penerapan pengendalian internal berbasis Sarbanes-Oxley act yang efektif akan memperbaiki sistem informasi perusahaan dan mengurangi fraud atas penyajian laporan keuangan. Kualitas audit dapat ditingkatkan dengan auditor independen yang kompeten serta menjunjung tinggi standar audit dan etika profesi.

Keandalan pelaporan keuangan secara langsung berpengaruh negatif dan signifikan terhadap kualitas audit dengan $p$-value sebesar $0.033<0,05$. Opini audit merupakan mediasi parsial hubungan antara keandalan pelaporan keuangan terhadap kualitas audit dengan nilai $p$-value sebesar $0.033<0,05$. Pelaporan keuangan yang andal dapat memperbaiki kualitas audit laporan keuangan melalui opini audit wajar tanpa pengecualian dan bebas dari salah saji material (fraud). 
Variabel opini audit berpengaruh negatif dan signifikan terhadap kualitas audit dengan nilai $p$-value sebesar 0,02 < 0,05. Perusahaan publik di Indonesia akan menekankan kepada kualitas audit atas informasi keuangan. Prosedur audit dan perilaku auditor yang sesuai dengan standar audit umum yaitu kompetensi dan auditor independen, tentunya dapat memitigasi fraud atas laporan keuangan audit.

\section{SIMPULAN, KETERBATASAN DAN IMPLIKASI HASIL PENELITIAN}

\section{Simpulan}

Berdasarkan hasil pengujian hipotesis dalam penelitian ini, maka dapat diambil kesimpulan berikut.

1. Hasil penelitian menunjukkan bahwa penerapan Sarbanes-Oxley Act berpengaruh positif dan signifikan terhadap opini audit. Penerapan SarbanesOxley Act yang dilaksanakan dengan baik akan berpotensi dalam perolehan opini audit wajar tanpa pengecualian.

2. Hasil penelitian menunjukkan bahwa keandalan pelaporan keuangan berpengaruh positif dan signifikan terhadap opini audit. Jika keandalan pelaporan keuangan sudah relevan dan reliabel maka berpotensi memperoleh opini audit wajar tanpa pengecualian.

3. Penerapan pengendalian internal berbasis Sarbanes-Oxley Act tidak berpengaruh signifikan terhadap kualitas audit. Keandalan pelaporan keuangan secara langsung berpengaruh negatif terhadap kualitas audit.

4. Keandalan pelaporan keuangan berpengaruh secara langsung dan signifikan terhadap kualitas audit.

5. Opini audit berpengaruh negatif terhadap kualitas audit, yang berarti bahwa semakin buruk opini audit yang diberikan oleh auditor maka semakin tinggi kualitas audit dalam proses audit yang dilakukan.

6. Pengendalian internal berbasis Sarbanes-Oxley Act tidak dimediasi oleh opini audit, karena auditor menganggap penerapan internal kontrol berbasis Sarbanes-Oxley Act bukan merupakan faktor yang mereka pertimbangkan dalam meningkatkan kualitas audit laporan keuangan. Opini audit memediasi secara parsial hubungan antara keandalan pelaporan keuangan terhadap kualitas audit.

\section{Keterbatasan Penelitian}

Beberapa keterbatasan dalam penelitian ini yang masih perlu menjadi bahan acuan untuk penelitian selanjutnya berikut ini.

1. Kurangnya sumber referensi tentang penerapan pengendalian internal berbasis Sarbanes-Oxley Act dan keandalan pelaporan keuangan terhadap opini auditor. 
2. Penelitian ini terbatas pada objek penelitian profesi auditor internal yang bekerja pada sejumlah perusahaan publik di Jakarta. Sehingga hasil penelitian tidak dapat digeneralisasi untuk mewakili seluruh auditor internal di Indonesia. Selain itu, pengukuran seluruh variabel didasarkan pada persepsi responden saja.

\section{Implikasi Hasil Penelitian dan Riset Mendatang}

Berdasarkan hasil penelitian, maka implikasinya adalah sebagai berikut.

1. Hasil penelitian ini dapat digunakan secara luas pada semua jenis industri di perusahaan publik sebagai bahan pertimbangan untuk meningkatkan pengendalian internal berbasis Sarbanes-Oxley Act yang efektif dan efisien dalam rangka memitigasi fraud untuk meningkatkan keandalan pelaporan keuangan perusahaan dan kualitas audit.

2. Bagi peneliti selanjutnya, perlu memasukkan faktor lain yang diperkirakan berinteraksi dengan opini atas pelaporan keuangan, seperti kelengkapan laporan keuangan menggunakan International Financial Reporting Standard, bukti audit yang memadai dan peran pengendalian internal berbasis SarbanesOxley Act untuk memitigasi fraud.

\section{DAFTAR PUSTAKA}

AAA Financial Accounting Standard Committee. 2000. Commentary: SEC auditor independence requirements. Accounting Horizons. Vol.15 No.4: 373-386.

Adeyemi, S. B., dan T. O. Fagbemi. 2010. Audit quality, corporate governance and firm characteristics in Nigeria. International Journal of Business and Management. Vol.5 No.5: 169-179.

Adeyemi, S. B., dan O. M. Uadiale. 2010. The impact of firm characteristics and corporate governance variables on audit fees in Nigeria. Nigerian Journal of Management Studies. Vol.10 No.2: 1-22.

AICPA. 1988. Code of Professional Conduct. New York: AICPA.

AICPA. 1997. Joint Ethics Enforcement Program (JEEP): Manual of Procedures. New York: AICPA.

Arens, A. A., Elder dan Beasley. 2008. Auditing dan Jasa Assurance Pendekatan Terintegrasi, Jilid I Edisi Keduabelas (edisi terjemahan). Jakarta: Penerbit Erlangga.

Beneish, M. D., M. B. Billings, dan L. D. Hodder. 2008. Internal control weaknesses and information uncertainty, Indiana University. The Accounting Review. Vol.83 No.5: 665-703. 
Boyton, W. G. J., N. Raymon, dan W. G. Kell. 2001. Modern Auditing. New Jersey: John Wiley \& Sons, Inc.

DeAngelo, L. E. 1981a. Auditor independence, 'low balling', and disclosure regulation. Journal of Accounting and Economics. Vol.3: 113-127.

DeAngelo, L. E. 1981b. Auditor size and audit quality. Journal of Accounting and Economics. Vol.3:183-199.

Deis, D., dan G. Giroux. 1992. Determinants of audit quality in the public sector. The Accounting Review. Vol.67 No.3: 462-479. 1996. The effect of auditor changes on audit fees, audit hours, and audit quality. Journal of Accounting and Public Policy. Vol.15 No.1: 55-76.

Elisha, M. S., dan B. I. Rangga. 2010. pengaruh independensi, pengalaman, due professional care, dan akuntabilitas terhadap kualitas audit. Simposium Nasional Akuntansi XIII.

Felix, W. L. Jr., A. A. Gramling, dan M. J. Maletta. 2001. The contribution of internal audit as a determinant of external audit fees and factors influencing this contribution. Journal of Accounting Research (December): 513-534.

Felix, W. L. Jr., A. A. Gramling, dan M. J. Maletta. 1998. Coordinating Total Audit Coverage: The Relationship Between Internal and External Auditors. Altamonte Springs, FL: The Institute of Internal Auditors. Inc.

Freeman, R. E. 2010. Strategic manajemen: A stakehorder approach. Cambridge University Press.

Ghozali, I. 2011. Aplikasi Analisis Multivariate dengan Program SPSS, Cetakan kelima. Semarang: Badan Penerbit Universitas Diponegoro.

Ghozali, I., dan Latan. 2014. Partial Least Squares-Konsep Metode Dan Aplikasi, menggunakan Program WarpPLS 4.0. Second Edition. Semarang: Badan Penerbit Universitas Diponegoro.

Goldman, A., dan B. Barlev. 1974. The auditor-firm conflict of interests: Its implications for independence. The Accounting Review. Vol.49 (October): 707-718.

Ikatan Akuntansi Indonesia. 2007. Standar Akuntansi Keuangan. Jakarta: Salemba Empat.

Ikatan Akuntansi Indonesia. 2011. Standar Profesi Akuntan Publik. Jakarta: Salemba Empat.

Konrath, L. F. 2002. Auditing Concepts and Applications, A Risk-Analysis Approach, $5^{\text {th }}$ Edition. West Publishing Company. 
Krishnamoorthy, G. 2001. A cascaded inference model for evaluation of the internal audit report. Decision Sciences. Vol.32: 499-520.

Lai Kam-Wah. 2003. The sarbanes-oxley act and auditor independence: Preliminary evidence from audit opinion and discretionary accruals, department of accountancy, City University of Hong Kong. Social Science Research Network Electronic Paper Collection.

Lennox, C. S. 1999. audit quality and auditor size: An evaluation of reputation and deep pockets hypotheses. Journal of Business Finance \& Accounting. Vol.26 No.7 \& 8 (September/Oktober).

Mansouri, A., R. Pirayesh, dan M. Salehi. 2009. Audit competence and audit quality: case in emerging economy. International Journal of Business and Management. Vol.4 No.2: 17-25.

Murdijaningsih, T. 2014. Sarbanes-Oxley role in the detections financial statement fraud in Telkom to support good corporate governance. Economics Faculty Wijayakusuma University, Purwokerto.

Nichols, D., dan K. Price. 1976. The auditor-firm conflict: An analysis using concepts of exchange theory. The Accounting Review: 335-346.

Pusat Bahasa Departemen Pendidikan Nasional. 2002. Kamus Besar Bahasa Indonesia, Edisi Ketiga. Jakarta: Balai Pustaka.

Sugiyono. 2009. Metode Penelitian Bisnis. Cetakan keempat belas. Bandung: Alfabeta.

Sugirachmawati dan Djaddang. 2014. Pengaruh penerapan sarbanex oxley act dan keandalan pelaporan keuangan terhadap opini audit. Riset. FEB UMB, Jakarta.

Suraida. 2005. Pengaruh etika, kompetensi, pengalaman audit dan risiko audit terhadap skeptisisme profesional auditor dan ketetapan pemberian opini akuntan publik. Jurnal Sosiohumaniora. Vol.7 No.3: 186-202. 


\section{LAMPIRAN}

Tabel 7

Operasionalisasi Variabel

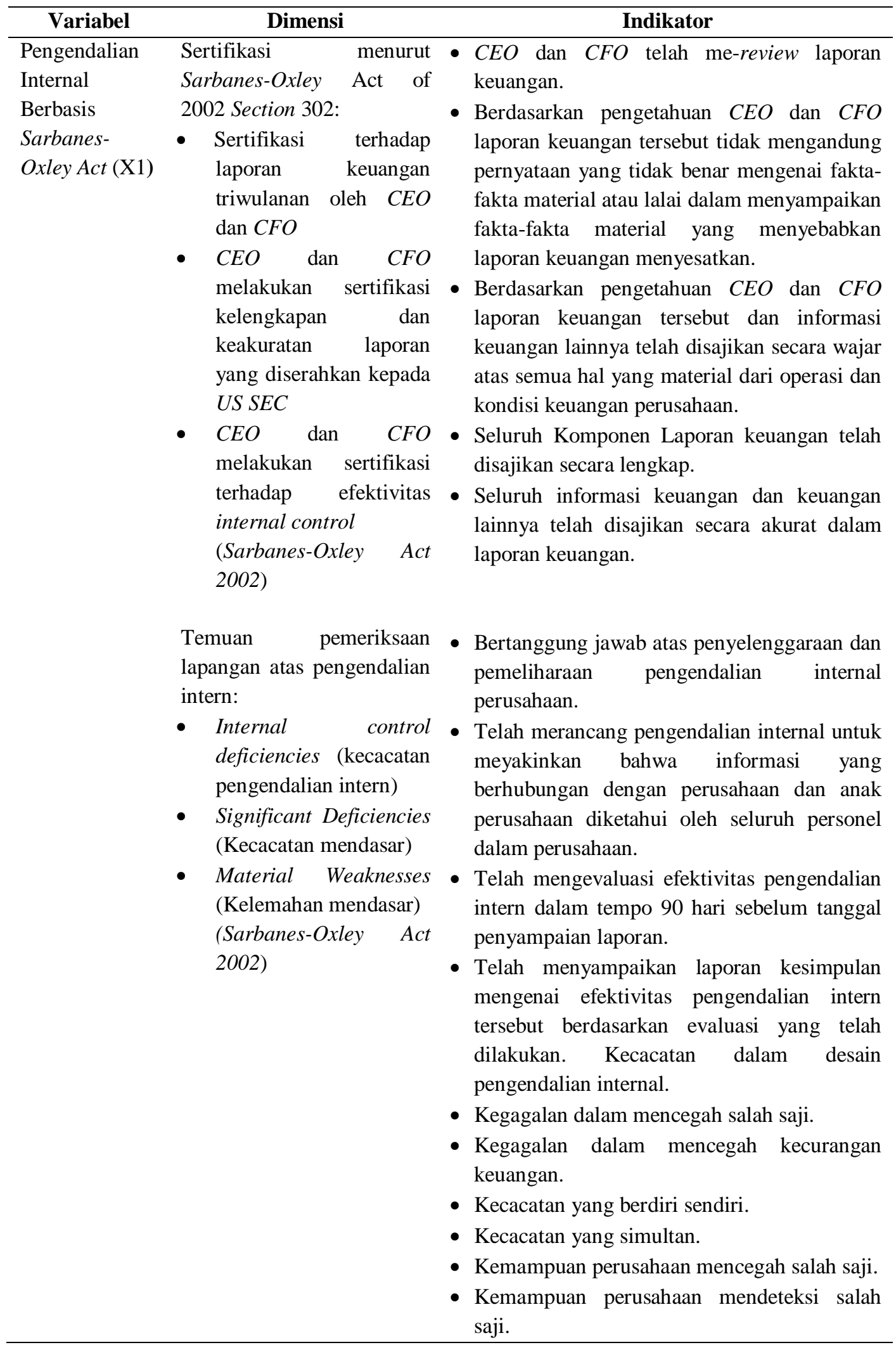


Tabel 7 (Lanjutan)

Operasionalisasi Variabel

\begin{tabular}{|c|c|c|}
\hline Variabel & Dimensi & Indikator \\
\hline $\begin{array}{l}\text { Keandalan } \\
\text { pelaporan } \\
\text { Keuangan (X2) }\end{array}$ & $\begin{array}{l}\text { - Tidak ada pembatasan } \\
\text { atas ruang lingkup } \\
\text { pekerjaan auditor }\end{array}$ & $\begin{array}{l}\text { - Informasi harus menggambarkan dengan } \\
\text { jujur transaksi serta peristiwa lainnya yang } \\
\text { seharusnya disajikan atau yang secara wajar. } \\
\text { - Dalam menyusun dan menerapkan ukuran } \\
\text { dan teknik pengujian sesuai dengan makna } \\
\text { transaksi dan peristiwa. } \\
\text { - Setiap transaksi serta peristiwa lain yang } \\
\text { seharusnya disajikan, dicatat dan disajikan } \\
\text { sesuai dengan substansi dan realitas ekonomi } \\
\text { dan bukan hanya bentuk hukumnya. } \\
\text { - Informasi yang disajikan tidak mengarah } \\
\text { pada satu kepentingan tertentu namun lebih } \\
\text { pada kepentingan bersama. } \\
\text { - Informasi yang disajikan tidak mengandung } \\
\text { unsur untuk menguntungkan atau merugikan } \\
\text { pihak tertentu. } \\
\text { - Mengandung unsur kehati-hatian pada saat } \\
\text { melakukan perkiraan dalam kondisi } \\
\text { ketidakpastian. } \\
\text { - Informasi disajikan dengan mengacu pada } \\
\text { ketentuan dan peraturan yang berlaku atau } \\
\text { pada standar yang sudah ada. } \\
\text { - Informasi yang disajikan dalam laporan } \\
\text { keuangan harus lengkap dalam batasan } \\
\text { materialitas dan biaya. } \\
\text { - Informasi harus diungkapkan serta } \\
\text { menyeluruh sesuai dengan transaksi serta } \\
\text { peristiwa yang terjadi. } \\
\text { Auditor dapat mengumpulkan bukti audit } \\
\text { yang mencukupi. } \\
\text { standar audit. }\end{array}$ \\
\hline
\end{tabular}


Tabel 7 (Lanjutan)

Operasionalisasi Variabel

\begin{tabular}{llll}
\hline \multicolumn{1}{c}{ Variabel } & \multicolumn{1}{c}{ Dimensi } & \multicolumn{1}{c}{ Indikator } \\
\hline Kualitas Audit & - Telaah dari rekan & - Telaah dari rekan seprofesi dan sikap \\
(Y) & - Jasa non-audit yang & auditor dengan rekan seprofesi. \\
& diberikan oleh KAP & - Pemberian jasa non-audit, gaji eksekutif, \\
& - Standar audit, yaitu & dan pemberian jasa legal. \\
& standar umum, standar & - Melaporkan semua kesalahan klien, sistem \\
& pekerjaan lapangan, & $\begin{array}{l}\text { informasi akuntansi klien, komitmen yang } \\
\text { kuat, pekerjaan lapangan tidak percaya } \\
\text { dan standar pelaporan }\end{array}$ & $\begin{array}{l}\text { pernyataan klien dan pengambilan } \\
\text { keputusan. }\end{array}$ \\
& &
\end{tabular}

Sumber: Arens et al. (2008)

Tabel 8

Pengujian Model Fit and General Result

Average path coefficient $(A P C)=0.275, P=0.002$

Average $R$-squared $(A R S)=0.396, P<0.001$

Average adjusted $R$-squared $(A A R S)=0.344, P<0.001$

Average block VIF $(A V I F)=2.276$, acceptable if $<=5$, ideally $<=3.3$

Average full collinearity VIF $($ AFVIF $)=2.091$, acceptable if $<=5$, ideally $<=3.3$

Tenenhaus GoF $(\mathrm{GoF})=0.629$, small $>=0.1$, medium $>=0.25$, large $>=0.36$

Sympson's paradox ratio $(S P R)=0.800$, acceptable if $>=0.7$, ideally $=1$

$R$-squared contribution ratio $(R S C R)=0.981$, acceptable if $>=0.9$, ideally $=1$

Statistical suppression ratio $(S S R)=1.000$, acceptable if $>=0.7$

Nonlinear bivariate causality direction ratio $(N L B C D R)=1.000$, acceptable if $>=0.7$

Sumber: Data primer yang diolah (2014) 
Tabel 9

Indirect and total Effects

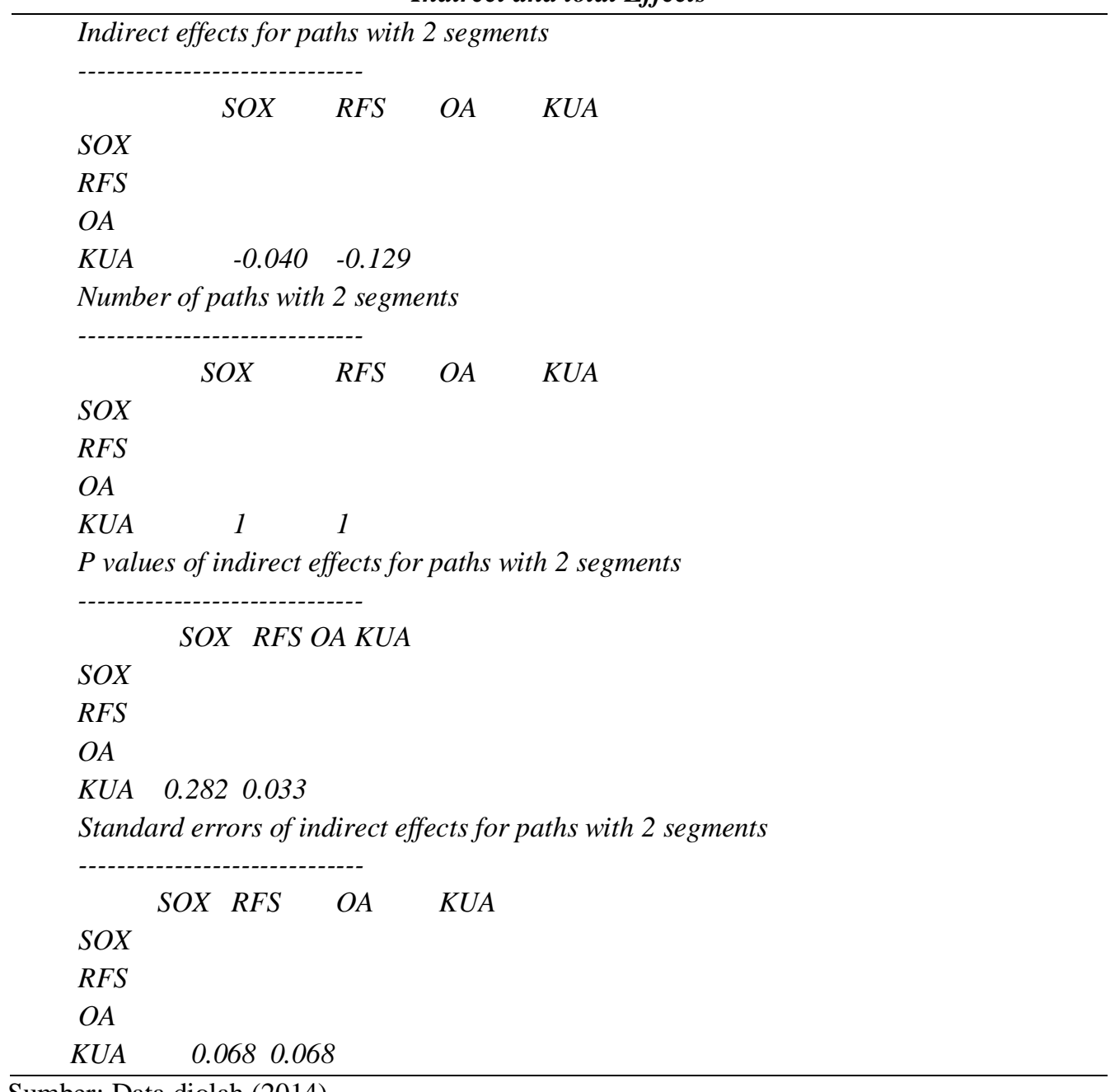

Sumber: Data diolah (2014)

Tabel 10

R-Squared Contributions

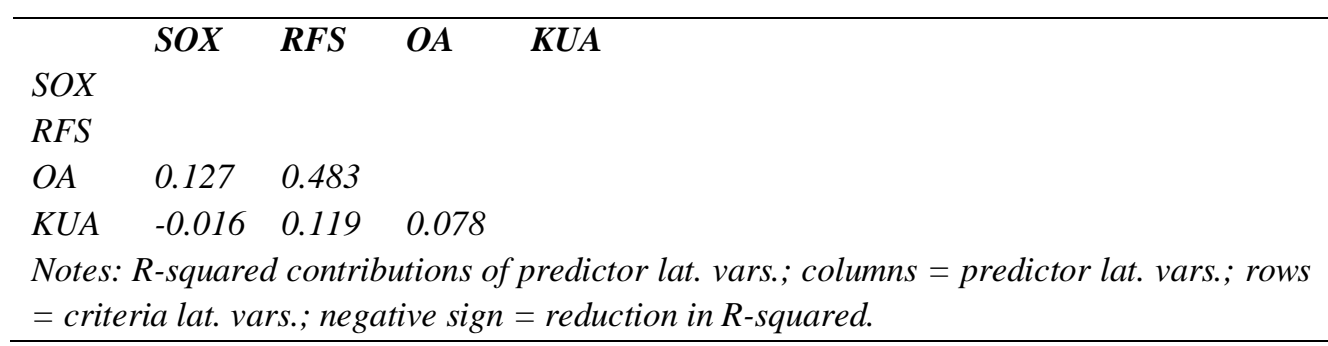

Sumber: Data diolah (2014) 
